\title{
Introductory Artillery Mathematics and Antiaircraft Mathematics
}





\section{Introductory Artillery Mathematics and Antiaircraft Mathematics}

$$
\text { By S่OPHIA H. LEVY }
$$

UNIVERSITY OF CALIFORNIA PRESS BERKELEY AND LOS ANGELES 1943 


\title{
UNIVERSITY OF CALIFORNIA PRESS \\ BERKELEY AND LOS ANGELES \\ CALIFORNIA \\ CAMBRIDGE UNIVERSITY PRESS \\ LONDON, ENGLAND
}

\author{
COPYRIGHT, 1943, BY \\ SOPHIA H. LEVY
}




\section{PREFACE}

This book has been written for the use of men in the armed services of the United States, primarily for those engaged in the antiaircraft service. It concerns itself with the parts of mathematics essential to their work; it has been kept brief in the hope that brevity would increase its usefulness.

The trial shot problem has received emphasis; descriptions of slide rules have been included; tables, a protractor, and a slide rule will be found at the back of the book. Only type problems have been given and all have been solved completely.

The writer has been privileged to instruct about one thousand men of the 101st Coast Artillery Brigade, Fourth Antiaircraft Command (AA). Many of them have subsequently completed their courses at the Antiaircraft Artillery Officer Candidate School, Camp Davis, North Carolina.

This book is dedicated to students in my own classes in antiaircraft mathematics, past, present, and future.

SopHIA H. Levy

Associate Professor of Mathematics

University of California

Berkeley, California

March, 1943 
